\title{
Corrosion Behavior of Low-Carbon Steel and Weathering Steel in a Coastal Zone of the Spratly Islands: A Tropical Marine Atmosphere
}

\author{
Yuwei Liv ${ }^{1,2}$, Hongtao Zhao ${ }^{1}$, Zhenyao Wang ${ }^{1, *}$,Yinghua Wei ${ }^{1}$, Chen Pan ${ }^{l}$, Chenxi Lv $^{l}$ \\ ${ }^{1}$ Institute of Metal Research, Chinese Academy of Sciences, Wencui Rd 62, Shenyang, 110016, China \\ ${ }^{2}$ School of Materials Science and Engineering, University of Science and Technology of China, \\ Wencui Rd 62, Shenyang, 110016, China \\ *E-mail: zhywang@imr.ac.cn
}

doi: $10.20964 / 2020.07 .48$

Received: 7 March 2020 / Accepted: 11 April 2020 / Published: 10 June 2020

\begin{abstract}
For the first time, the initial atmospheric corrosion behavior of low-carbon steel and weathering steel, exposed in a tropical marine zone of the Spratly Islands, has been examined over one year. The results indicated that the corrosion products were mainly composed of $\beta-\mathrm{FeOOH}, \alpha-\mathrm{FeOOH}, \gamma-\mathrm{FeOOH}$, and $\mathrm{Fe}_{3} \mathrm{O}_{4}$. The transformation between each phase and the cracking, linearly arrayed voids distributed in the rust layer together promoted the corrosion process. The kinetics of both steels exhibited an accelerating process following the exponential function $D=A t^{n}$. In terms of the corrosion rate, $r_{\text {corr }}$, for the first year of exposure to different corrosivity categories defined in ISO 9223, that of the low-carbon steel Q235 exposed in the Spratly Islands was $237.5 \mu \mathrm{m} / \mathrm{a}$; therefore, the corrosivity category of this marine atmosphere was CX.
\end{abstract}

Keywords: Low-carbon steel Q235; Weathering steel Q450NQR1; Corrosion depth; Spratly Islands; Atmospheric corrosion

\section{FULL TEXT}

(C) 2020 The Authors. Published by ESG (www.electrochemsci.org). This article is an open access article distributed under the terms and conditions of the Creative Commons Attribution license (http://creativecommons.org/licenses/by/4.0/). 